\title{
Pengaruh CR (Current Ratio), DER (Debt to Equity Ratio), EPS (Earning Per Share) dan Financial Distress (Altman Score) Terhadap Harga Saham Pada Perusahaan Sektor Industri Dasar dan Kimia Yang Terdaftar Di Bursa Efek Indonesia
}

Jessy Safitri Sitorus Universitas Prima Indonesia sitorusjessy7@gmail.com

\author{
Evelyn \\ Universitas Prima Indonesia \\ evelynnkwo97@gmail.com
}

Funny

Universitas Prima Indonesia

funnyhuimei22@gmail.com

\author{
Jeanny Gunawan \\ Universitas Prima Indonesia \\ jeanny.gunawan98@gmail.com
}

\begin{abstract}
ABSTRAK
Tujuan dari penelitian ini agar dapat mengetahui analisis fundamental yang berpengaruh didalam harga saham. Variabel independen pada penelitian ini adalah current ratio, debt to equity ratio, earning per share dan financial distress (altman score), sedangkan variabel dependen pada penelitian ini adalah harga saham. Penelitian ini diambil dari perusahaan sektor industri dasar dan kimia yang terdaftar di BEI pada tahun 2013-2017. Populasi yang terdapat dalam sektor perusahaan tersebut adalah 69 perusahaan. Sampel yang diteliti adalah sebanyak 24 perusahaan yang diseleksi menggunakan teknik purposive sampling sehingga total sampel yang akan digunakan selama 5 tahun menjadi 120 sampel. Metode analisis yang digunakan adalah analisis regresi linier berganda dengan alat bantu SPSS 21 . Hasil pengujian secara parsial menunjukkan bahwa current ratio berpengaruh negatif signifikan terhadap harga saham, debt to equity ratio tidak berpengaruh secara signifikan terhadap harga saham, earning per share dan financial distress (altman score) berpengaruh positif signifikan terhadap harga saham pada perusahaan sektor industri dasar dan kimia.
\end{abstract}

Kata kunci : Current Ratio, Debt to Equity Ratio, Earning Per Share, Financial Distress (Altman Score), Harga Saham

\section{Pendahuluan}

\subsection{Latar belakang}

Arus ekonomi dunia yang cenderung melambat berakibat pada perekonomian negara berkembang, seperti negara Indonesia diprediksi tidak mengalami peningkatan yang relatif. Hal ini disebabkan konflik dagang negara China dan Amerika Serikat yang secara tidak langsung mengalami penurunan terhadap keadaan ekonomi global. Negara yang memegang kendali terbesar terhadap perekonomian dunia adalah Amerika Serikat. Artinya, arus pergerakan mata uang kurs dollar memegang kendali bagi perekonomian di Indonesia, dimana lemahnya kurs rupiah pada dollar di tahun 2015 ternyata berimbas pada sebagian besar 
saham di pasar modal negara Indonesia. Pergerakan ekonomi yang fluktuatif mempengaruhi ketertarikan para investor, sehingga pada saat yang bersamaan, IHSG juga mengalami penurunan nilai yang drastis. Kondisi ini dapat diketahui dari adanya keputusan dari 10 sektor saham pada pasar modal yang memilih untuk menahan ekspansi usahanya. Sektor industri dasar dan kimia merupakan salah satu sektor saham yang mengalami penurunan paling drastis di tahun 2015 dengan penurunan sebesar 35,66\%. Dampaknya pun berpengaruh terhadap kinerja pada setiap emitennya, diantaranya TKIM menurun sebesar $41,74 \%$, JPFA menurun sebesar $33,16 \%$ dan SMGR menurun sebesar 29,63\% dari tahun 2014. (https://www.google.com/amp/s/m.liputan 6.com/amp/2309792/ekonomi-lesu-10sektor-saham-kompak-melemah)

Perusahaan tentu membutuhkan dana untuk menjalankan keuangan perusahaan tersebut. Tujuan dari pendanaan tersebut salah satunya adalah untuk melunasi hutang perusahaan. Untuk memperoleh dana, salah satu cara adalah dengan mendaftarkan sahamnya ke pasar modal / Bursa Efek Indonesia. Sahamsaham yang diperjualbelikan oleh perusahaan kepada calon investor yang kelak akan digunakan untuk mengekspansi usahanya. Para investor yang berniat membeli saham perusahaan harus memiliki acuan untuk menilai kelayakan dari suatu saham perusahaan. Salah satu acuan yang dapat digunakan investor adalah menggunakan rasio likuiditas untuk menilai kemampuan keuangan internal dari perusahaan, sehingga perusahaan akan memperoleh laba dari hasil investasinya.

Tingkat rasio utang yang besar tidak selalu menurunkan minat para investor untuk menanamkan sahamnya. Karena keputusan investor dapat ditinjau dari dua bentuk utang, baik itu dana yang dipinjam untuk menggerakkan kinerja perusahaan atau dana yang dipinjam untuk menutupi kerugian perusahaan. Sehingga, seorang investor harus mampu menganalisis terlebih dahulu saham suatu perusahaan.

Perusahaan yang memiliki tingkat laba yang tinggi tentu memiliki pengaruh yang besar terhadap harga saham. Oleh sebab itu, investor harus bijak dalam memilih saham. Earning per share dapat dijadikan acuan investor untuk menginvestasikan sahamnya. Rasio ini dapat menentukan harga saham yang berpotensi laba yang besar bagi para investor, sehingga hal tersebut dapat membantu proses pengambilan keputusan.

Perusahaan yang memiliki citra buruk dan hutang yang banyak biasanya cenderung akan mengalami kebangkrutan. Untuk itu, cara yang dapat digunakan para investor adalah dengan menguji rasio kebangkrutan, agar dapat mempertimbangkan kembali untuk melakukan pembelian saham perusahaan tersebut.

Adapun beberapa penelitian sebelumnya yang dapat membantu untuk lebih memahami tentang harga saham, yaitu :

Peneliti Setiyawan dan Pardiman (2014) dalam penelitiannya yang berjudul "Pengaruh Current Ratio, Inventory Turnover, Time Interest Earned Dan Return On Equity Terhadap Harga Saham Pada Perusahaan Manufaktur Sektor Barang Konsumsi Yang Terdaftar di BEI Periode 2009-2012”. Hasil dari penelitiannya menyimpulkan bahwa Current Ratio berpengaruh positif dan signifikan terhadap harga saham.

Peneliti Rahmawati dan Suryono (2017) dalam penelitiannya yang berjudul 
"Pengaruh DPR, EPS, Dan DER Terhadap Harga Saham". Hasil dari peneltiannya mengungkapkan bahwa DER berpengaruh positif dan signifikan terhadap harga saham.

Peneliti Dewi dan Suaryana (2013) dalam penelitiannya yang berjudul "Pengaruh EPS, DER, Dan PBV Terhadap Harga Saham". Hasil dari peneltiannya menyatakan bahwa EPS berpengaruh positif dan signifikan terhadap harga saham.

Peneliti Wiryani (2018) dalam penelitiannya yang berjudul "Z-Score Bankruptcy Prediction Model And Stock Prices Of The Cigarette Companies In Indonesia". Hasil dari peneltiannya menyimpulkan bahwa Z-Score berpengaruh positif terhadap harga saham.

Dari beberapa penelitian diatas, maka peneliti tertarik untuk melakukan penelitian kembali dengan judul, "Pengaruh CR (Current Ratio), DER (Debt to Equity Ratio), EPS (Earning Per Share) Dan Financial Distress (Altman Score) Terhadap Harga Saham Pada Perusahaan Sektor Industri Dasar Dan Kimia Yang Terdaftar di Bursa Efek Indonesia."

\subsection{Rumusan Masalah}

Adapun rumusan masalah dalam penelitian ini adalah :

1. Bagaimana pengaruh $\mathrm{CR}$ (Current Ratio) terhadap Harga Saham pada perusahaan sektor industri dasar dan kimia yang terdaftar di Bursa Efek Indonesia periode 2013 - 2017 ?

2. Bagaimana pengaruh DER (Debt to Equity Ratio) terhadap Harga Saham pada perusahaan sektor industri dasar dan kimia yang terdaftar di Bursa Efek Indonesia periode 2013 - 2017 ?

3. Bagaimana pengaruh EPS (Earning Per Share) terhadap Harga Saham pada perusahaan sektor industri dasar dan kimia yang terdaftar di Bursa Efek Indonesia periode 2013 - 2017 ?

4. Bagaimana pengaruh Financial Distress (Altman Score) terhadap Harga Saham pada perusahaan sektor industri dasar dan kimia yang terdaftar di Bursa Efek Indonesia periode 2013 -2017 ?

\section{Tinjauan Pustaka}

\subsection{Current Ratio}

Setiyawan dan Pardiman (2014) menyatakan bahwa current ratio diperoleh untuk mengukur likuiditas dengan aset lancar dan hutang lancar. Menurut Novitasari dan Herlambang (2015), indikator yang digunakan untuk menghitung Current Ratio dapat dinyatakan dengan rumus :

$$
\text { Current Ratio }=\frac{\text { Current Assets }}{\text { Current Liabilities }}
$$

\subsection{Debt to Equity Ratio}

Rahmawati dan Suryono (2017) mengatakan bahwa rasio ini dipergunakan dalam mengukur kemampuan perusahaan membiayai total hutang menggunakan modalnya sendiri Indikator yang digunakan untuk menghitung Debt to Equity Ratio dapat dinyatakan dengan rumus :

$$
\text { Debt to Equity Ratio }=\frac{\text { Total Hutang }}{\text { Total Ekuitas }}
$$

\subsection{Earning Per Share}

Bahri dan Darmayanti (2017) mendefinisikan bahwa perbandingan antara laba bersih yang didapat setelah pajak dengan jumlah saham yang beredar. Menurut Rachman dan Sutrisno (2013), indikator yang digunakan untuk 
menghitung Earning Per Share dapat dinyatakan dengan rumus :

$$
\text { EPS }=\frac{\text { EAT }}{\text { Jumlah Saham Yang Beredar }}
$$

\subsection{Financial Distress}

Rodoni dan Ali (2014:186) mengatakan bahwa situasi ketika arus kas operasi suatu perusahaan tidak cukup untuk memenuhi kewajiban dalam perusahaannya sehingga dilakukan perbaikan perusahaan Menurut Sanjaya (2018), indikator yang digunakan untuk menghitung Financial Distress dapat dinyatakan dengan rumus :

$\mathrm{Z}=1,2 \mathrm{X}_{1}+1,4 \mathrm{X}_{2}+3,3 \mathrm{X}_{3}+0,6 \mathrm{X}_{4}+1,0 \mathrm{X}_{5}$

\subsection{Harga Saham}

Mujati dan Dzulqodah (2016) mengatakan bahwa harga saham merupakan harga pasar yang tercatat pada waktu penutupan (closing price). Pengukuran harga saham ini menggunakan skala nominal, dimana dilihat dari closing price setiap tahun.

\subsection{Pengaruh Current Ratio (CR) Terhadap Harga Saham}

Rahayu dan Dana (2016)

mengungkapkan bahwa current ratio menunjukkan kesanggupan perusahaan akan kewajiban yang dimiliki perusahaan. Dimana tingginya current ratio dapat menunjukkan performa perusahaan yang baik dalam meningkatkan nilai perusahaan akan diikuti oleh meningkatnya harga saham.

Octaviani dan Komalasari (2017) menyatakan bahwa perusahaan dikatakan dalam situasi yang baik jika sanggup membayar kewajiban jangka pendeknya, serta dapat meningkatkan harga saham sehingga memikat para investor untuk berinvestasi dalam situasi perusahaan saat ini.

Rachman dan Sutrisno (2013) menyimpulkan bahwa tingginya current ratio menunjukkan besarnya kesanggupan perusahaan dalam menutupi kewajibannya. Nilai aset lancar yang tinggi membuat investor lebih menyukai menanamkan modalnya melalui pembelian saham.

Secara umum, pengaruh Current Ratio terhadap harga saham dapat disimpulkan bahwa Current Ratio digunakan untuk mengetahui besarnya kesanggupan perusahaan dalam melunasi hutang-hutang jangka pendeknya,sehingga membuat investor tertarik berinvestasi dan mengakibatkan harga saham melonjak.

$\mathrm{H}_{1}$ :Current Ratio berpengaruh terhadap Harga Saham.

\subsection{Pengaruh Debt to Equity Ratio (DER) Terhadap Harga Saham}

Nur'aidawati (2018) mengutarakan bahwa tingginya hutang dapat mempengaruhi ekuitas. DER yang tinggi menandakan kewajiban yang harus dibayar semakin besar sehingga tingkat profit semakin kecil dan dapat berakibat buruk pada harga saham.

Utami dan Darmawan (2018) mengemukakan bahwa tinggi rendahnya DER dapat mempengaruhi harga saham. DER yang tinggi dapat menjadi pertanda buruk dan dapat mengurangi keinginan para investor untuk menanam modal pada perusahaan tersebut.

Pratama dan Erawati (2014) menyimpulkan bahwa jika modal asing operasional perusahaan kecil dapat menunjukkan rendahnya DER yang dapat menaikkan harga saham dan menunjukkan kecilnya resiko bagi investor.

Pengaruh Debt to Equity Ratio secara umum terhadap harga saham dapat 
disimpulkan bahwa perusahaan yang tingkat DERnya tinggi berarti perusahaan tersebut susah untuk membayar kewajibannya yang mengakibatkan investor ragu untuk berinvestasi.

$\mathrm{H}_{2} \quad$ : Debt to Equity Ratio berpengaruh terhadap Harga.

\subsection{Pengaruh Earning per Share (EPS) Terhadap Harga Saham \\ Rahmawati dan Suryono (dalam} Setiyanto dan Hadi : 2017) menyatakan bahwa informasi EPS dapat digunakan investor untuk memaparkan laba di masa mendatang. Nilai EPS yang tinggi dapat memikat investor untuk berinvestasi sehingga dapat meningkatkan permintaan akan saham dan harga saham.

Alipudin dan Oktaviani (2016) menjelaskan bahwa suatu perusahaan dalam membagikan devidennya ditinjau dari nilai EPS yang artinya semakin kecilnya nilai EPS maka pembagian deviden semakin kecil .

Dewi dan Suaryana (2013) mengungkapkan bahwa EPS memaparkan profit yang akan didapatkan investor. EPS yang tinggi ditandai dengan harga saham yang tinggi, dikarenakan EPS dapat menjadi acuan bagi investor untuk menganalisa saham terlebih dahulu sebelum berinvestasi.

Secara umum Earning Per Share berdampak terhadap harga saham, sehingga dari pengertian di atas disimpulkan bahwa tingginya EPS dapat membuat harga saham meningkat sehingga para investor berminat untuk menginvestasikan modalnya karena Earning Per Share mempengaruhi besarnya laba yang diberikan oleh perusahaan.

$\mathrm{H}_{3} \quad$ : Earning Per Share berpengaruh terhadap Harga Saham.

\subsection{Pengaruh Financial Distress (Altman Score) Terhadap Harga Saham}

Kartini dan Pahlevi (2012)

menyimpulkan bahwa pengujian kebangkrutan menggunakan model Altman dapat menentukan pergerakan harga saham. Prediksi kebangkrutan bermanfaat bagi pihak investor agar mempunyai gambaran mengenai perkembangan usaha. Tingginya harga saham menunjukkan pertumbuhan perusahaan dalam memikat para investor untuk bertransaksi dan menanamkan modalnya.

Sukmawati,dkk. (2014) menyatakan bahwa model Altman merupakan alat uji yang dapat memprediksikan tingkat kebangkrutan suatu perusahaan. Dimana semakin bagus rasio keuangan model Altman, maka dapat menunjukkan kesehatan perusahaan yang lebih baik. Hal ini dapat menarik banyak investor untuk melakukan transaksi pembelian saham sehingga peningkatan harga saham perusahaan dapat meningkat.

Wiyarni (2018) mengemukakan bahwa tinggi rendahnya pergerakan harga saham dapat disebabkan adanya pertimbangan investor. Kondisi yang menjadi pertimbangan seperti kinerja suatu perusahaan yang baik atau tidak mengalami kesulitan keuangan akan mempengaruhi harga saham.

Secara umum, pengaruh financial distress terhadap harga saham dapat disimpulkan bahwa model Altman adalah salah satu alat uji untuk memprediksi kebangkrutan dalam sebuah perusahaan, dimana dapat mempengaruhi pergerakan saham perusahaan tersebut sehingga dapat membuat para investor melakukan peninjauan kembali sebelum melakukan transaksi.

$\mathrm{H}_{4} \quad$ : Financial Distress berpengaruh terhadap Harga Saham. 


\section{Metode Penelitian \\ 3.1 Metodologi Penelitian}

Penelitian ini termasuk metode pendekatan kuantitatif. Sugiyono (2016:11) mengungkapkan bahwa penelitian kuantitatif yaitu metode penelitian ini menggunakan analisis statistik. Jenis penelitian yang dipakai ialah statistik deskriptif yang memberikan gambaran berupa data statistik secara sistematis sehingga tidak membentuk kesimpulan yang bersifat umum. Adapun teknik pengumpulan data dalam penelitian ini melalui studi dokumentasi. Data yang dikumpulkan berasal dari laporan keuangan perusahaan sektor industri dasar dan kimia yang dimuat dalam situs resmi Bursa Efek Indonesia periode 2013-2017, yaitu www.idx.co.id 〈http://www.idx.co.id> beserta situs terkait www.sahamok.com <http://www.sahamok.com>. Jenis data yang digunakan bersifat kuantitatif. Sumber data yang digunakan berupa data sekunder yang didapat dengan mengunduh laporan keuangan yang di publikasi secara rutin di situs Bursa Efek Indonesia, yaitu www.idx.co.id 〈http://www.idx.co.id>.

\subsection{Populasi dan Sampel}

Populasi yang terdapat dalam penelitian ini sebanyak 69 perusahaan sektor industri dasar dan kimia yang terdaftar di Bursa Efek Indonesia periode 2013-2017. Teknik penarikan sampel dengan menggunakan purposive sampling. Sugiyono (2016:215) mengungkapkan bahwa purposive sampling merupakan salah satu teknik dalam mengambil sampel dengan beberapa pertimbangan tertentu. Adapun kriteria yang digunakan dalam menentukan sampel oleh peneliti, yaitu :

\section{Tabel 1. Kriteria Pengambilan}

\begin{tabular}{|c|c|c|}
\hline \multicolumn{3}{|c|}{ Sampel Penelitian } \\
\hline No. & Kriteria & $\begin{array}{l}\text { Jumlah } \\
\text { Sampel }\end{array}$ \\
\hline 1. & $\begin{array}{l}\text { Perusahaan sektor industri } \\
\text { dasar dan kimia yang terdaftar } \\
\text { di Bursa Efek Indonesia } \\
\text { periode } 2013-2017 \text {. }\end{array}$ & 69 \\
\hline 2. & $\begin{array}{l}\text { Perusahaan sektor industri } \\
\text { dasar dan kimia yang telah } \\
\text { pindah sektor di Bursa Efek } \\
\text { Indonesia periode } 2013- \\
\text { 2017. }\end{array}$ & $(10)$ \\
\hline 3. & $\begin{array}{l}\text { Perusahaan sektor industri } \\
\text { dasar dan kimia yang tidak } \\
\text { mempublikasikan laporan } \\
\text { keuangan secara rutin tiap } \\
\text { tahun selama periode 2013- } \\
2017 \text {. }\end{array}$ & (3) \\
\hline 4. & $\begin{array}{l}\text { Perusahaan sektor industri } \\
\text { dasar dan kimia yang tidak } \\
\text { memiliki laba bersih periode } \\
\text { 2013-2017. }\end{array}$ & $(32)$ \\
\hline & $\begin{array}{l}\text { ah perusahaan yang menjadi } \\
\text { sampel penelitian } \\
\end{array}$ & 24 \\
\hline Da & observasi penelitian $(5 \times 24)$ & 120 \\
\hline
\end{tabular}

\section{Hasil dan Pembahasan \\ 4.1 Statistik Deskriptif}

Uji statistik deskriptif dilakukan untuk mengetahui deskripsi data penelitian yang ditunjukkan dari hasil rata-rata (mean) sebagai besarnya rata rata populasi yang diperkirakan dari sampel, maksimumminimum nilai dalam populasi dan standar deviasi (standard deviation) dalam menilai rata-rata dispersi dari sampel yang digunakan. Hasil analisis statistik deskriptif dapat dilihat di bawah ini sebagai berikut :

Tabel 2. Statistik Deskriptif

\begin{tabular}{|l|r|r|r|r|r|}
\hline & N & Minimum & Maximum & Mean & Std. Deviation \\
\hline CR & 120 &, 87 & 15,16 & 3,2869 & 3,13970 \\
DER & 120 &, 08 & 5,15 &, 8966 &, 93450 \\
EPS & 120 & 1,84 & 1438,29 & 226,8213 & 362,42671 \\
ALTMAN & 120 &, 68 & 16,35 & 4,4796 & 3,60548 \\
HARGA_SAHAM & 120 & 50,00 & 25000,00 & 3041,2833 & 5219,09364 \\
Valid N (listwise) & 120 & & & & \\
\hline
\end{tabular}




\subsection{Uji Asumsi Klasik}

\subsubsection{Uji Normalitas}

Ghozali (2013:154) menyatakan bahwa uji ini bertujuan untuk mengetahui nilai residual apakah terdistribusi normal atau tidak. Penelitian ini menggunakan uji Histogram, Scatterplot dan KolmogorovSmirnov. Jika nilai signifikansi lebih besar dari 5\% atau 0,05 maka Ho diterima, yang berarti data berdistribusi normal dan $\mathrm{Ha}$ ditolak. Hasil dari pengujiannya adalah sebagai berikut :

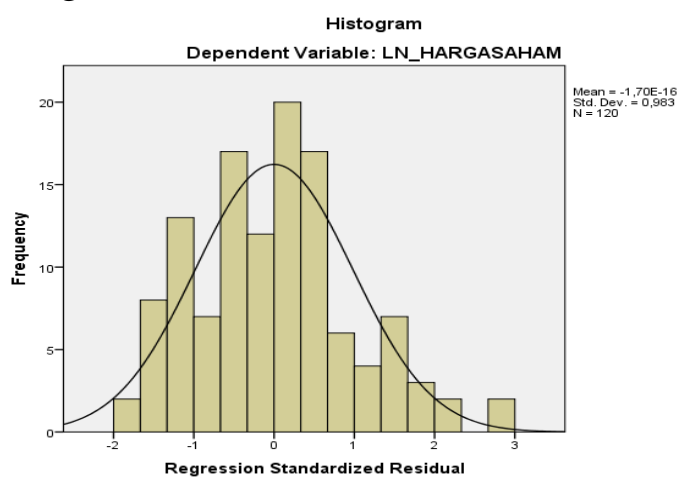

\section{Gambar 1. Grafik Uji Normalitas} Histogram (Setelah Transformasi)

Grafik histogram diatas merupakan grafik yang telah mengalami transformasi data, sehingga dapat menunjukkan kurva berbentuk lonceng ( $U$ terbalik). Grafik histogram yang baik adalah grafik yang memulai garis kurva pada sumbu y dari angka 0 , sehingga hasil uji normalitas pada grafik histogram tersebut menunjukkan data berdistribusi normal.

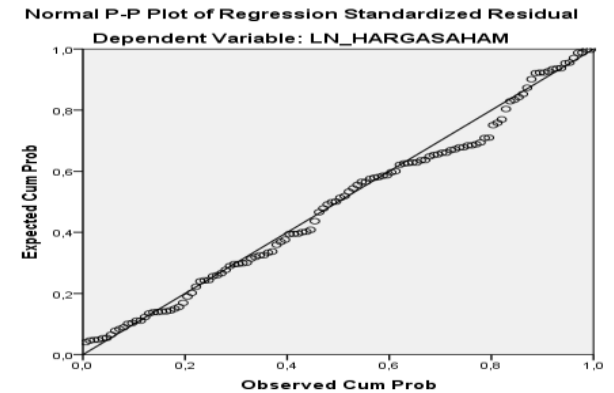

Gambar 2. Grafik Uji Normalitas

\section{P - Plot (Setelah Transformasi)}

Grafik Normalitas P-P Plot pada gambar di atas, terlihat titik-titik menyebar mendekati garis diagonal ,sehingga dapat dikatakan data telah berdistribusi normal.

Tabel 3. Uji Normalitas Kolmogorov Smirnov (Setelah Transformasi)

One-Sampel Kolmogorov-Smirnov Test

\begin{tabular}{ll|r|}
\hline & & Unstandardized Residual \\
\hline N & & 120 \\
Normal Parameters & Mean &, 0000000 \\
& Std. Deviation &, 63276081 \\
& Absolute &, 087 \\
Most Extreme Differences & Positif &, 087 \\
& Negatif &,- 041 \\
Kolmogorov-Smirnov Z & &, 952 \\
Asymp. Sig. (2-tailed) & &, 325 \\
\hline \\
a. Test distribution is Normal. \\
b. Calculated from data.
\end{tabular}

Hasil uji statistik Kolmogorov Smirnov dapat dikatakan bahwa variabel Current Ratio $\left(\mathrm{X}_{1}\right)$, Debt to Equity Ratio $\left(\mathrm{X}_{2}\right)$, Earning Per Share $\left(\mathrm{X}_{3}\right)$, Altman Score $\left(\mathrm{X}_{4}\right)$ dan Harga Saham (Y) sudah memenuhi syarat distribusi normal karena nilai signifikan $0,325>0,05$ dengan demikian model regresi ini layak digunakan untuk dianalisis.

\subsubsection{Uji Multikolinearitas}

Ghozali (2013:103) mengemukakan bahwa uji ini digunakan untuk mengetahui ada tidaknya hubungan kuat antar variabel independent. Apabila tolerance value $>0,1$ atau VIF $<10$, maka dapat disimpulkan tidak terjadi multikolinearitas. Hasil dari pengujian multikoliniearitas yang digunakan dalam penelitian ini adalah sebagai berikut : 
Tabel 4. Uji Multikolinearitas

\begin{tabular}{|c|c|c|c|c|c|c|c|}
\hline \multirow[t]{2}{*}{ Model } & \multicolumn{2}{|c|}{$\begin{array}{l}\text { Unstandardized } \\
\text { Coefficients }\end{array}$} & \multirow{2}{*}{$\begin{array}{c}\begin{array}{c}\text { Standardized } \\
\text { Coefficients }\end{array} \\
\text { Beta }\end{array}$} & \multirow[t]{2}{*}{$\mathrm{T}$} & \multirow[t]{2}{*}{ Sig. } & \multicolumn{2}{|c|}{$\begin{array}{l}\text { Collinearity } \\
\text { Statistics }\end{array}$} \\
\hline & B & Std. Error & & & & Tolerance & VIF \\
\hline (Constant) & 3,130 &, 181 & & 17,315 & .000 & & \\
\hline LN_CR &,- 467 &, 161 &,- 222 & $-2,906$ & .004 & 242 & 4,134 \\
\hline 1 LN_DER &, 154 &, 141 &, 095 & 1,093 & 277 &, 186 & 5,372 \\
\hline LN_EPS & .792 &, 039 &, 827 & 20,176 & .000 & 840 & 1,190 \\
\hline LN_ALTMAN &, 706 &, 108 & 359 & 6,505 &, 000 & 462 & 2,164 \\
\hline
\end{tabular}

Berdasarkan tabel diatas batas tolerance value adalah 0,1 dan batas VIF adalah 10. Apabila tolerance value $>0,1$ atau VIF $<10$, maka tidak terjadi multikolinearitas. Nilai tolerance variabel Current Ratio $\left(\mathrm{X}_{1}\right)$, Debt to Equity Ratio $\left(\mathrm{X}_{2}\right)$, Earning Per Share $\left(\mathrm{X}_{3}\right)$, Altman Score $\left(\mathrm{X}_{4}\right)$ berada diatas 0,1 sedangkan nilai VIF variabel Current Ratio $\left(\mathrm{X}_{1}\right)$, Debt to Equity Ratio $\left(\mathrm{X}_{2}\right)$ dan Earning Per Share $\left(\mathrm{X}_{3}\right)$, Altman Score $\left(\mathrm{X}_{4}\right)$ berada dibawah 10. Dengan demikian dari hasil uji multikolinearitas dapat diambil kesimpulan tidak terjadi multikolinearitas yang berarti tidak terdapat korelasi antar variabel independen.

\subsubsection{Uji Autokorelasi}

Untuk dapat mengetahui apakah dalam model regresi linear adanya korelasi terhadap periode $\mathrm{t}$ dengan periode $\mathrm{t}-1$ (sebelumnya), Ghozali (2013:107). Adapun rumus yang digunakan $\mathrm{du}<\mathrm{dw}<4-\mathrm{du}$. Jika nilai D-W terletak antara -2 sampai +2 maka tidak ada autokorelasi, sedangkan nilai D-W lebih besar dari 2 maka terjadi autokorelasi.
Tabel 5. Uji Autokorelasi : (Setelah Transformasi)

Model Summary ${ }^{b}$

\begin{tabular}{l|r|r|r|r|r|}
\hline Model & $R$ & $R$ Square & $\begin{array}{r}\text { Adjusted R } \\
\text { Square }\end{array}$ & $\begin{array}{r}\text { Std. Error of the } \\
\text { Estimate }\end{array}$ & Durbin-Watson \\
\hline 1 &, $915^{\mathrm{a}}$ &, 838 &, 832 &, 64367 & 1,850 \\
\hline
\end{tabular}
a. Predictors: (Constant), LN_ALTMAN, LN_EPS, LN_CR, LN_DER
b. Dependent Variabel: LN_HARGASAHAM

Berdasarkan tabel diatas menunjukkan besarnya nilai Durbin Watson sebesar 1,850 . Nilai D-W menurut tabel $\mathrm{n}=120$ dan $\mathrm{k}=4$ didapat nilai $\mathrm{dl}=1,6339$ dan $\mathrm{du}=1,7715$, sehingga $\mathrm{du}<$ $\mathrm{dw}<4-\mathrm{du}$ memenuhi syarat yakni 1,7715 $<1,850<2,2285$. Maka dapat ditarik kesimpulan bahwa data terbebas dari masalah autokorelasi.

\subsubsection{Uji Heterokedastisitas}

Bertujuan untuk mengetahui apakah terdapat ketidaksamaan varians didalam grafik scatterplot dan uji Park dari residual satu pengamatan ke pengamatan lainnya, Ghozali (2013:134). Kriteria pengujian scatterplot adalah dengan melihat titik-titik menyebar secara acak baik diatas maupun dibawah angka nol (0) pada sumbu Y. Kriteria pengujian uji Park adalah dengan melihat nilai Sig. > 0,05. Apabila Sig. > 0,05 , maka Ho diterima dan Ha ditolak yang berarti model fit dengan data sehingga data terbebas dari Heteroskedastisitas.

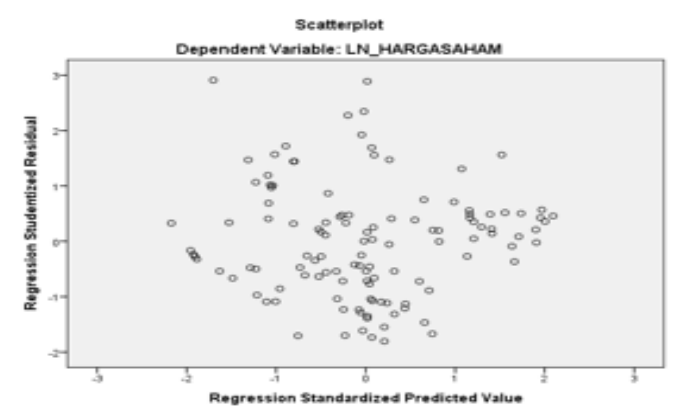

Gambar 3.Grafik Uji Heteroskedasisitas Scatterplot (Setelah Transformasi) 
Berdasarkan gambar diatas terlihat bahwa titik-titik menyebar secara acak tersebar baik diatas maupun dibawah angka nol (0) pada sumbu Y, tidak berkumpul disatu tempat, sehingga dapat disimpulkan bahwa tidak terjadi heteroskedastisitas pada model regresi.

Pendeteksian ada tidaknya heteroskedastisitas bisa juga dilakukan dengan menggunakan metode uji park, yaitu dengan cara mengkorelasikan nilai variabel independen dengan logaritma natural residual kuadrat.

Tabel 6. Uji Park

(Setelah Transformasi)

Coefficients $^{\mathbf{a}}$

\begin{tabular}{|c|c|c|c|c|c|}
\hline \multirow[t]{2}{*}{ Model } & \multicolumn{2}{|c|}{$\begin{array}{l}\text { Unstandardized } \\
\text { Coefficients }\end{array}$} & \multirow{2}{*}{$\begin{array}{c}\text { Standardized } \\
\text { Coefficients }\end{array}$} & \multirow[t]{2}{*}{$\mathrm{t}$} & \multirow[t]{2}{*}{ Sig. } \\
\hline & B & Std. Error & & & \\
\hline (Constant) & $-1,104$ & .639 & & $-1,727$ & .087 \\
\hline LN_CR & .537 & .569 &, 174 & 945 & 347 \\
\hline 1 LN_DER &, 076 & 498 & .032 &, 152 & 879 \\
\hline LN_EPS &,- 217 &, 139 &,- 155 & $-1,564$ &, 121 \\
\hline LN_ALTMAN &,- 514 &, 384 &,- 179 & $-1,340$ & ,183 \\
\hline
\end{tabular}

Berdasarkan tabel diatas menunjukkan bahwa variabel Current Ratio sebesar 0,347; Debt to Equity Ratio sebesar 0,879; Earning Per Share sebesar 0,121; dan Altman Score sebesar 0,183 lebih besar dari 0,05 maka dapat ditarik kesimpulan bahwa data diatas terbebas dari masalah heteroskedastisitas.

\subsection{Hasil Analisis Data Penelitian}

Pengujian hipotesis penelitian dapat dilakukan dengan beberapa jenis analisis. Berikut ini adalah model regresi yang dapat digunakan untuk menganalisis data :
Tabel 7. Persamaan Regresi

\begin{tabular}{|c|c|c|c|c|c|c|c|}
\hline \multicolumn{8}{|c|}{ Coefficients $^{\mathrm{a}}$} \\
\hline \multirow[t]{2}{*}{ Model } & \multicolumn{2}{|c|}{$\begin{array}{l}\text { Unstandardized } \\
\text { Coefficients }\end{array}$} & \multirow{2}{*}{\begin{tabular}{|c|}
$\begin{array}{c}\text { Standardized } \\
\text { Coefficients }\end{array}$ \\
Beta \\
\end{tabular}} & \multirow[t]{2}{*}{$\mathrm{T}$} & \multirow[t]{2}{*}{ Sig. } & \multicolumn{2}{|c|}{$\begin{array}{c}\text { Collinearity } \\
\text { Statistics }\end{array}$} \\
\hline & B & Std. Error & & & & Tolerance & VIF \\
\hline (Constant) & 3,130 & .181 & & 17,315 & .000 & & \\
\hline LN_CR &,- 467 &, 161 &,- 222 & $-2,906$ &, 004 &, 242 & 4,134 \\
\hline 1 LN_DER &, 154 &, 141 &, 095 & 1,093 & .277 &, 186 & 5,372 \\
\hline LN_EPS & .792 & .039 & 827 & 20,176 &, 000 & 840 & 1,190 \\
\hline LN_ALTMAN &, 706 &, 108 &, 359 & 6,505 &, 000 &, 462 & 2,164 \\
\hline
\end{tabular}

Berdasarkan tabel diatas diperoleh rumus regresi sebagai berikut :

LN_Harga Saham $=3,130-0,467(\mathrm{CR})+$ $0,154($ DER $)+0,792($ EPS $)+0,706$

(ALTMAN)

Berdasarkan nilai dari persamaan regresi linear di atas maka koefisienkoefisien tersebut dapat diartikan sebagai berikut :

1. Nilai konstanta $(\alpha) \quad 3,130$ menunjukkan apabila variabel LN_CR $\left(\mathrm{X}_{1}\right), \mathrm{LN} \_\mathrm{DER}\left(\mathrm{X}_{2}\right), \mathrm{LN}$ _EPS $\left(\mathrm{X}_{3}\right)$ dan LN_ALTMAN $\left(\mathrm{X}_{4}\right)$ sama dengan 0 maka harga saham (Y) akan mengalami kenaikan sebesar 3,130 satuan.

2. Pada koefisien $\beta 1=-0,467$ menunjukkan adanya pengaruh negatif antara variabel $\mathrm{CR}\left(\mathrm{X}_{1}\right)$ terhadap harga saham (Y). Dimana kenaikan 1 satuan pada variabel $\mathrm{CR}\left(\mathrm{X}_{1}\right)$, dengan asumsi bahwa variabel bebas lainnya konstan, maka harga saham juga akan mengalami penurunan sebesar 0,467 satuan.

3. Pada koefisien $\beta 2=0,154$ menunjukkan adanya pengaruh positif antara variabel DER $\left(\mathrm{X}_{2}\right)$ terhadap harga saham (Y). Dimana kenaikan 1 satuan pada variabel DER $\left(\mathrm{X}_{2}\right)$, dengan asumsi bahwa variabel bebas lainnya konstan, maka harga saham juga akan 
mengalami peningkatan sebesar 0,154 satuan.

4. Pada koefisien $\beta 3=0,792$ menunjukkan adanya pengaruh positif antara variabel EPS $\left(\mathrm{X}_{3}\right)$ terhadap harga saham (Y). Dimana kenaikan 1 satuan pada variabel EPS $\left(\mathrm{X}_{3}\right)$, dengan asumsi bahwa variabel bebas lainnya konstan, maka harga saham juga akan mengalami peningkatan sebesar 0,792 satuan.

5. Pada koefisien $\quad \beta 4=0,706$ menunjukkan adanya pengaruh positif antara variabel ALTMAN $\left(\mathrm{X}_{4}\right)$ terhadap harga saham (Y). Dimana kenaikan 1 satuan pada variabel ALTMAN $\left(\mathrm{X}_{4}\right)$, dengan asumsi bahwa variabel bebas lainnya konstan, maka harga saham juga akan mengalami peningkatan sebesar 0,706 satuan.

\subsection{Koefisien Determinasi Hipotesis}

Digunakan untuk memprediksi seberapa besar kontribusi pengaruh variabel x secara simultan terhadap variabel y,Ghozali (2013:95). Kriteria pengujiannya adalah nilai $\mathrm{R}^{2}$ yang mendekati 0 berarti variabel bebas tidak menjelaskan sedikit pun mengenai variabel terikat, sebaliknya apabila nilai $\mathrm{R}^{2}$ mencapai angka 1 berarti variabel bebas dapat memberikan penjelasan untuk memprediksi variabel terikat.

Tabel 8. Koefisien Determinasi Model Summary ${ }^{b}$

\begin{tabular}{|c|c|c|c|c|c|}
\hline Model & $\mathrm{R}$ & R Square & Adjusted R Square & $\begin{array}{c}\text { Std. Error of } \\
\text { the Estimate }\end{array}$ & Durbin-Watson \\
\hline 1 &, $915^{\mathrm{a}}$ &, 838 &, 832 &, 64367 & 1,850 \\
\hline
\end{tabular}

a. Predictors: (Constant), LN_ALTMAN, LN_EPS, LN_CR, LN_DER

b. Dependent Variabel: LN_HARGASAHAM
Uji Koefisien Determinasi menunjukkan bahwa nilai dari Adjusted $R$ Square menghasilkan 0,832, yang artinya pengaruh yang diberikan oleh Current Ratio, Debt to Equity Ratio, Earning Per Share dan Altman Score sebesar 83,2\% terhadap harga saham, sedangkan 16,8\% lainnya dipengaruhi oleh variabel lainnya yang tidak dibahas.

\subsection{Uji Secara Parsial (Uji-t)}

Ghozali(2013:171) mengemukakan bahwa uji t ini digunakan untuk mengetahui tingkat signifikansi pengaruh variabel bebas secara parsial. Kriteria pengujiannya adalah $\mathrm{t}$ hitung $>\mathrm{t}$ tabel dengan nilai signifikansi 0,05 . Hasil pengujian dengan uji ini adalah sebagai berikut :

\section{Tabel 9. Uji t}

Coefficients $^{\mathrm{a}}$

\begin{tabular}{|c|c|c|c|c|c|c|c|}
\hline \multirow[t]{2}{*}{ Model } & \multicolumn{2}{|c|}{$\begin{array}{c}\text { Unstandardized } \\
\text { Coefficients }\end{array}$} & \multirow{2}{*}{\begin{tabular}{|c|}
$\begin{array}{c}\text { Standardized } \\
\text { Coefficients }\end{array}$ \\
Beta \\
\end{tabular}} & \multirow[t]{2}{*}{$\mathrm{t}$} & \multirow[t]{2}{*}{ Sig. } & \multicolumn{2}{|c|}{$\begin{array}{l}\text { Collinearity } \\
\text { Statistics }\end{array}$} \\
\hline & B & Std. Error & & & & Tolerance & VIF \\
\hline (Constant) & 3,130 &, 181 & & 17,315 & .000 & & \\
\hline LN_CR &,- 467 &, 161 &,- 222 & $-2,906$ & .004 & 242 & 4,134 \\
\hline 1 LN_DER &, 154 &, 141 & 095 & 1,093 & .277 &, 186 & 5,372 \\
\hline LN_EPS & ,792 &, 039 & .827 & 20,176 & .000 & 840 & 1,190 \\
\hline LN_ALTMAN & ,706 & 108 &, 359 & 6,505 & .000 & 462 & 2,164 \\
\hline
\end{tabular}

Berdasarkan pada tabel uji t bahwa :

1. Pada variabel CR (Current Ratio) dapat dilihat bahwa nilai $t$ hitung sebesar -2,906 dengan nilai signifikansi 0,05 , sedangkan nilai $\mathrm{t}$ tabel adalah sebesar 1,981 maka hal ini menunjukkan bahwa thitung $<\mathrm{t}$ tabel yaitu $-2,906<-1,981$. Artinya variabel CR (Current Ratio) secara parsial berpengaruh negatif signifikan terhadap harga saham pada perusahaan sektor industri dasar dan kimia yang 
terdaftar di Bursa Efek Indonesia periode 2013-2017.

2. Pada variabel DER (Debt to Equity Ratio) dapat dilihat bahwa nilai $\mathrm{t}$ hitung sebesar 1,093 dengan nilai signifikansi 0,05 , sedangkan nilai $\mathrm{t}$ tabel adalah sebesar 1,981 maka hal ini menunjukkan bahwa $t$ hitung $<\mathrm{t}$ tabel yaitu $1,093<1,981$. Artinya variabel DER (Debt to Equity Ratio) secara parsial tidak berpengaruh signifikan terhadap harga saham pada perusahaan sektor industri dasar dan kimia yang terdaftar di Bursa Efek Indonesia periode 2013-2017.

3. Pada variabel EPS (Earning Per Share) dapat dilihat bahwa nilai $t$ hitung sebesar 20,176 dengan nilai signifikansi 0,05 , sedangkan nilai $\mathrm{t}$ tabel adalah sebesar 1,981 maka hal ini menunjukkan bahwa $\mathrm{t}$ hitung $>\mathrm{t}$ tabel yaitu 20,176>1,981. Artinya variabel EPS (Earning Per Share) secara parsial berpengaruh positif signifikan terhadap harga saham pada perusahaan sektor industri dasar dan kimia yang terdaftar di Bursa Efek Indonesia periode 2013-2017.

4. Pada variabel Altman Score dapat dilihat bahwa nilai $\mathrm{t}$ hitung sebesar 6,505 dengan nilai signifikansi 0,05 , sedangkan nilai t tabel adalah sebesar 1,981 maka hal ini menunjukkan bahwa t hitung > t tabel yaitu 6,505 > 1,981. Artinya variabel Altman Score secara parsial berpengaruh positif signifikan terhadap harga saham pada perusahaan sektor industri dasar dan kimia yang terdaftar di Bursa Efek Indonesia periode 2013-2017.

\subsection{Pembahasan Pengaruh Current Ratio Terhadap Harga Saham}

Berdasarkan hasil penelitian yang telah dilakukan, diperoleh hasil bahwa nilai Current Ratio terhadap harga saham yang diperoleh dari nilai $\mathrm{t}$ hitung $<\mathrm{t}$ tabel atau $2,906<-1,981$ yang menyatakan bahwa Current Ratio secara parsial berpengaruh negatif signifikan terhadap harga saham. Harga pasar dari harga saham yang bersangkutan tidak dipengaruhi oleh Current Ratio yang rendah, sebaliknya Current Ratio yang tinggi dapat dikarenakan kesanggupan perusahaan dalam membayar hutang jangka pendek namun banyak persediaan yang belum terjual. Penelitian ini sejalan dengan hasil penelitian dari Azmi,dkk. (2016) yang menyimpulkan bahwa Current Ratio berpengaruh negatif signifikan terhadap harga saham akan tetapi, tidak sejalan dengan penelitian yang dilakukan oleh Rahayu dan Dana (2016) yang menyatakan bahwa Current Ratio berpengaruh positif signifikan terhadap harga saham.

\subsection{Pembahasan Pengaruh Debt to Equity Ratio Terhadap Harga Saham}

Dari hasil penelitian yang dilakukan pada variabel Debt to Equity Ratio terhadap harga saham dapat diperoleh nilai t hitung $<\mathrm{t}$ tabel yaitu $1,093<1,981$ yang menyatakan Debt to Equity Ratio secara parsial tidak berpengaruh secara signifikan terhadap harga saham. Artinya, Debt to Equity Ratio tidak menjadi bahan pertimbangan bagi para investor saat membeli saham perusahaan, karena setiap penurunan maupun peningkatan pada Debt to Equity Ratio tidak mempengaruhi harga saham. Pada dasarnya setiap perusahaan membutuhkan hutang sebagai bantuan modal bagi kehidupan operasional perusahaan, dengan keadaan dimana 
perusahaan mampu mengendalikan nilai hutang perusahaan. Hal ini sejalan dengan penelitian yang dilakukan oleh Alipudin dan Oktaviani (2016) yang dalam penelitiannya menyatakan bahwa Debt to Equity Ratio tidak berpengaruh signifikan terhadap harga saham sedangkan hasil penelitian ini bertolak belakang dengan penelitian yang dilakukan oleh Dewi dan Suaryana (2013) yang menyatakan Debt to Equity berpengaruh signifikan terhadap harga saham.

\subsection{Pembahasan Pengaruh Earning Per Share Terhadap Harga Saham}

Pada hasil pengolahan data dapat dilihat bahwa $0.020 \mathrm{t}$ hitung $>\mathrm{t}$ tabel pada variabel Earning Per Share yaitu sebesar 20,176 > 1,981, maka dari itu dapat disimpulkan bahwa Earning Per Share berpengaruh positif signifikan bagi harga saham. Earning Per Share merupakan variabel yang harus diperhatikan oleh para investor sebelum menanamkan modalnya pada suatu perusahaan. Karena peningkatan nilai Earning Per Share juga diikuti dengan peningkatan harga saham sehingga dapat memikat para investor dalam berinvestasi. Hal ini sejalan dengan hasil penelitian dari Rahmawati dan Suryono (dalam Setiyanto dan Hadi : 2017) yang menyimpulkan bahwa Earning Per Share berpengaruh positif terhadap harga saham dan tidak sejalan dengan penelitian yang dilakukan oleh Rahmadewi dan Abudanti (2018) dimana diperoleh hasil bahwa Earning Per Share berpengaruh negatif terhadap harga saham.

\subsection{Pembahasan Pengaruh Financial Distress (Altman Score) Terhadap Harga Saham}

Dari hasil uji dapat diperoleh nilai t hitung > t tabel yaitu $6,505>1,981$ sehingga dapat disimpulkan bahwa nilai Altman Score pada perusahaan industri dasar dan kimia yang terdaftar di Bursa Efek Indonesia secara parsial berpengaruh positif signifikan terhadap harga saham. Nilai dari Altman Score sangat penting bagi seorang investor sebelum menanamkan sahamnya pada suatu perusahaan, karena dengan mengetahui peningkatan nilai Altman Score, menunjukkan kondisi finansial perusahaan berada dalam keadaan menuju kebangkrutan. Dimana hasil penelitian ini juga didukung dengan hasil penelitian dari Wiyarni (2018), menurutnya Altman Score memberikan pengaruh yang positif terhadap nilai dari harga saham namun tidak sesuai dengan hasil penelitian dari Iladina, Mardani dan ABS (2018) dimana Altman Score berpengaruh negatif dan tidak signifikan terhadap harga saham.

\section{KESIMPULAN DAN SARAN 5.1 Kesimpulan}

Penelitian ini menguji bagaimana pengaruh CR (Current Ratio), DER (Debt to Equity Ratio), EPS (Earning Per Share) dan Financial Distress (Altman Score) terhadap harga saham pada perusahaan sektor industri dasar dan kimia yang terdaftar di Bursa Efek Indonesia periode 2013 - 2017. Dari hasil penelitian ini dapat disimpulkan bahwa :

1. CR (Current Ratio) secara parsial berpengaruh negatif signifikan terhadap harga saham pada perusahaan sektor industri dasar dan kimia yang terdaftar di Bursa Efek Indonesia periode 2013 - 2017.

2. DER (Debt to Equity Ratio) secara parsial tidak berpengaruh secara signifikan terhadap harga saham pada perusahaan sektor industri dasar dan kimia yang terdaftar di Bursa Efek Indonesia periode 2013 - 2017. 
3. EPS (Earning Per Share) secara parsial berpengaruh positif signifikan terhadap harga saham pada perusahaan sektor industri dasar dan kimia yang terdaftar di Bursa Efek Indonesia periode 2013 - 2017.

4. Financial Distress (Altman Score) secara parsial berpengaruh positif signifikan terhadap harga saham pada perusahaan sektor industri dasar dan kimia yang terdaftar di Bursa Efek Indonesia periode 2013 - 2017.

\subsection{Saran}

Adapun saran-saran yang dapat diberikan sehubungan dengan penelitian yang telah dilakukan adalah sebagai berikut :

1. Bagi peneliti selanjutnya, diharapkan untuk dapat menambahkan variabel bebas dengan variabel lainnya selain variabel yang telah diteliti agar informasi mengenai pengaruh terhadap harga saham lebih lengkap, selain itu dapat memperpanjang periode penelitian serta memperbanyak sampel penelitian agar penelitian selanjutnya yang dihasilkan lebih tepat dan akurat.

2. Bagi investor, untuk lebih memperhatikan kinerja perusahaan dari segi stabilitas perusahaan, terutama laba tahunan perusahaan dan tingkat utang yang semakin rendah, sehingga kemungkinan terjadinya kebangkrutan lebih tipis, karena kinerja perusahaan mencerminkan harga pasar sahamnya.

3. Bagi Universitas Prima Indonesia, diharapkan hasil penelitian ini dapat dijadikan sumber referensi bagi peneliti lain yang ingin meneliti dengan jenis variabel yang berkaitan.

\section{DAFTAR PUSTAKA}

Alipudin, A. \& Oktaviani, R. (2016). Pengaruh EPS, ROE, ROA dan DER Terhadap Harga Saham Pada Perusahaan Sub Sektor Semen Yang Terdaftar di BEI. JIAFE (Jurnal Ilmiah Akuntansi Fakultas Ekonomi), 2(1), 1-22.

Azmi, M. U., Andini, R., \& Raharjo, K. (2016). Analisis Pengaruh Net Profit Margin (NPM), Return On Assets (ROA) dan Current Ratio (CR) Terhadap Harga Saham Emiten LQ45 Yang Terdaftar di Bursa Efek Indonesia Pada Tahun 20102014. Journal Of Accounting, 2(2).

Bahri, M. S., \& Darmayanti, N. P. A (2017). Pengaruh Current Ratio, Debt to Equity Ratio, Return On Equity, dan Earning Per Share Terhadap Harga Saham Pada Perusahaan Automotive and Allied di BEI. Prosiding Seminar Nasional AIMI Jambi, ISBN: 978-602-98081-7-9.

Dewi, P. D. A., \& Suaryana, I. G. N. A. (2013). Pengaruh EPS, DER, dan PBV Terhadap Harga Saham. EJurnal Akuntansi Universitas Udayana, 4(1), 215-229.

Ghozali, Imam. (2013). Aplikasi Analisis Multivariate Dengan Program IBM SPSS 21 (Edisi 7). Cetakan ke VII. Semarang: Badan Penerbit Universitas Diponegoro.

Iladina, F., Mardani, R. M., \& ABS M. K., (2018). Analisis Metode Altman ZScore Sebagai Alat Prediksi Kebangkrutan dan Pengaruhnya Terhadap Harga Saham Pada Perusahaan Tekstil dan Garmen Yang Terdaftar di Bursa Efek Indonesia Tahun 2014-2016. Jurnal Ilmiah Riset Manajemen, 7(2). 
Kartini \& Pahlevi, R. W. (2012). Hubungan Kinerja Keuangan Dengan Harga Saham Pada Perusahaan Manufaktur Yang Terdaftar di Bursa Efek Indonesia Periode Tahun 2007 - 2009 Dengan Pendekatan Altman Z Score. Jurnal Aplikasi Bisnis, 13(9).

Mujati, Y., \& Dzulqodah, M. (2016). Pengaruh Earning Per Share dan Price Earning Ratio Terhadap Debt to Equity Ratio dan Harga Saham Pada Perusahaan Sektor Makanan Dan Minuman di Bursa Efek Indonesia. Eksis: Jurnal Riset Ekonomi dan Bisnis, 11(1).

Novitasari, P., \& Herlambang, L. (2015). Pengaruh Current Ratio, Total Assets Turnover, Debt to Equity Ratio, dan Return On Equity Terhadap Harga Saham Pada Perusahaan Yang Terdaftar di JII Periode 2009-2013. JESTT, 2(4).

Nur'aidawati, S. (2018). Pengaruh Current Ratio (CR), Total Asset Turnover (TATO), Debt to Equity Ratio (DER) dan Return On Asset (ROA) Terhadap Harga Saham dan Dampaknya Pada Nilai Perusahaan (Studi Kasus Pada Sepuluh Bank Terbesar Yang Terdaftar di Bursa Efek Indonesia Periode Tahun 2011 2015). Jurnal Sekuritas (Saham, Ekonomi, Keuangan dan Investasi), 1(3).

Octaviani, S., \& Komalasari, D. (2017). Pengaruh Likuiditas, Profitabilitas, dan Solvabilitas Terhadap Harga Saham (Studi Kasus Pada Perusahaan Perbankan Yang Terdaftar di Bursa Efek Indonesia). JAK (Jurnal Akuntansi): Kajian Ilmiah Akuntansi, 3(2).
Pratama, A., \& Erawati, T. (2014). Pengaruh Current Ratio, Debt to Equity Ratio, Return On Equity, Net Profit Margin dan Earning Per Share Terhadap Harga Saham (Study Kasus Pada Perusahaan Manufaktur Yang Terdaftar di Bursa Efek Indonesia Periode 2008-2011). Jurnal Akuntansi, 2(1), 1-10.

Rachman, A. A., \& Sutrisno (2013). Analisis Pengaruh Faktor-Faktor Fundamental Terhadap Harga Saham Perusahaan Manufaktur. In Jurnal. Proceeding Seminar Nasional Dan Call For Papers Sancall. Surakarta. ISBN: 978-979-636-147-2.

Rahayu, N. M. P. S., \& Dana, I. M. (2016). Pengaruh EVA, MVA dan Likuiditas Terhadap Harga Saham Pada Perusahaan Food And Beverages. EJurnal Manajemen Universitas Udayana, 5(1).

Rahmadewi, P. W., \& Abundanti, N. (2018). Pengaruh EPS, PER, CR dan ROE Terhadap Harga Saham di Bursa Efek Indonesia. E-Jurnal Manajemen Unud, 7(4).

Rahmawati, D., \& Suryono, B. (2017). Pengaruh DPR, EPS, dan DER Terhadap Harga Saham. Sekolah Tinggi Ilmu Ekonomi Indonesia (STIESIA) Surabaya. Jurnal Ilmu Dan Riset Akuntansi, 6(6).

Rodoni, A. \& Ali, H. (2014), Manajemen Keuangan Modern. Jakarta: Mitra Wacana Media.

Sanjaya, S. (2018). Analisis Prediksi Kebangkrutan Perusahaan Dengan Menggunakan Metode Altman ZScore Pada Perusahaan Sektor Perkebunan Yang Terdaftar di Bursa Efek Indonesia (BEI) Periode 20112016. Jurnal Ilman, 6(2). 
Setiyanto, A. I., \& Hadi, A. (2014). Analisis Pengaruh Faktor Fundamental Terhadap Harga Saham (Studi Pada Perusahaan Sektor Properti di Asia Tenggara Tahun 2008-2012. Jurnal Akuntansi, Ekonomi dan Manajemen Bisnis, e-ISSN: 2548-9836, 2(2), 173-183.

Setiyawan, I., \& Pardiman, P. (2014). Pengaruh Current Ratio, Inventory Turn Over, Time Interest Earned dan Return On Equity Terhadap Harga Saham Pada Perusahaan Manufaktur Sektor Barang Konsumsi Yang Terdaftar di BEI Periode 20092012. Jurnal Nominal, Barometer Riset Akuntansi dan Manajemen, 3(2).

Sugiyono. (2016). Metode Penelitian Kuantitatif, Kualitatif dan $R \& D$. Bandung: PT Alfabet.

Sukmawati, N. M. D., Adiputra, I. M. P., SE, S., Si, M., Darmawan, N. A. S., \& SE, A. (2014). Pengaruh RasioRasio Dalam Model Altman Z Score
Terhadap Harga Saham (Studi Pada Perusahaan Perbankan Yang Go Public di Bursa Efek Indonesia). JIMAT (Jurnal Ilmiah Mahasiswa Akuntansi) Undiksha, 2(1).

Utami, M. R., \& Darmawan, A. (2018). Pengaruh DER, ROA, ROE, EPS dan MVA Terhadap Harga Saham Pada Indeks Saham Syariah Indonesia. Journal of Applied Managerial Accounting, 2(2), 77-89.

Wiyarni, C. A. M. (2018). Z-Score Bankruptcy Prediction Model and Stock Prices Of The Cigarette Companies in Indonesia. STIE Malangkucecwara Malang, East Java, Indonesia. International Journal of Business Marketing and Management (IJBMM), 3(10).

https://www.google.com/amp/s/m.liputan6 .com/amp/2309792/ekonomi-lesu-10sektor-saham-kompak-melemah www.idx.co.id www.sahamok.com 